\title{
WYDATKI NA DOBRA I USEUGI ZWIĄZANE Z ROZWOJEM INTELEKTUALNYM CZLONKÓW GOSPODARSTW DOMOWYCH Z PERSPEKTYWY WIEJSKICH BUDŻETÓW DOMOWYCH
}

\begin{abstract}
Zarys treści: Inwestowanie w dobra i usługi związane z kształceniem mogą przynieść wymierne efekty społeczne. W artykule skupiono się na analizie cech determinujących wydatki na rozwój intelektualny członków rodziny w wiejskich gospodarstwach domowych oraz dokonano porównania poziomu wydatków na kształcenie w zależności od miejsca lokalizacji, tj. uwzględniono gospodarstwa domowe zlokalizowane w największych miastach oraz gospodarstwa domowe zlokalizowane na wsiach. Wydaje się, że mimo licznych przeobrażeń polskiej wsi nadal utrzymują się znaczne różnice w modelach konsumpcji, także w odniesieniu do wydatków na kształcenie, między gospodarstwami domowymi z miast i ze wsi.
\end{abstract}

Słowa kluczowe: konsumpcja, gospodarstwo domowe, rozwój intelektualny, budżety gospodarstw domowych, wieś.

\section{Wprowadzenie}

Współcześnie inwestowanie $\mathrm{w}$ edukację wiąże się z presją społeczną dotyczącą zagwarantowania potomkom jak najlepszego wykształcenia. Przeświadczenie, że odpowiednie wykształcenie pomaga w zdobyciu pracy i wyższych dochodów, a także ułatwia adaptację do otoczenia, sprawia, że rola kształcenia zyskała i wciąż zyskuje na wartości. Dzieci już od najmłodszych lat uczęszczają na różnego rodzaju odpłatne zajęcia dodatkowe, dorośli uczestniczą w różnych odpłatnych kursach, szkoleniach i studiach. W gospodarstwach domowych ponoszone są również wydatki na różnego rodzaju wyjazdy turystyczne, na prasę, książki. Wszystkie te wydatki mają wpływ na rozwój intelektualny jednostek, przyczyniają się do pełniejszego poznania świata, do rozszerzenia światopoglądu.

Jakie zatem cechy wiejskich gospodarstw domowych determinują wydatki na kształcenie, jaka jest ich hierarchia? Ile mieszkańcy wsi, a ile ośrodków wielkomiejskich wydają na dobra i usługi związane z rozwojem intelektualnym? 
W opracowaniu wydatki na różnego rodzaju dobra i usługi związane z rozwojem intelektualnym członków gospodarstw domowych przeznaczane na wsiach zostaną skonfrontowane $\mathrm{z}$ wydatkami na te dobra $\mathrm{w}$ wielkomiejskich gospodarstwach domowych. Różniące się systemy wartości pomiędzy miejskimi i wiejskimi gospodarstwami domowymi mają wpływ na różnice we wzorach konsumpcji realizowanych w tych kategoriach gospodarstw (Wójcik 2008), przyczyniają się one do zgłaszania odmiennego zapotrzebowania na dobra i usługi (Gutkowska, Piekut 2014).

Celem opracowania jest ocena wielkości i struktury wydatków na dobra i usługi związane z rozwojem intelektualnym członków gospodarstw domowych mieszkających na polskich wsiach, a także wskazanie na czynniki determinujące te wydatki.

Podjęty problem badawczy wydaje się niezwykle istotny, gdyż lepiej wykształcone społeczeństwo to $\mathrm{w}$ konsekwencji większy potencjał rozwojowy (Dresler 2003), inwestycje w kształcenie stanowią o kapitale ludzkim (Kołaczek 2011), a większy potencjał tkwiący w danym narodzie prowadzi do wymiernych korzyści w przyszłości (Czapiewska 2014).

\section{Material badawczy i metodyka badania}

Materiał badawczy stanowiły indywidualne, niepublikowane dane $\mathrm{z}$ badania budżetów gospodarstw domowych GUS za 2012 rok. Dane pozyskano dla projektu badawczego „Badanie uwarunkowań poziomu konsumpcji $w$ gospodarstwach domowych ze szczególnym uwzględnieniem różnic między województwami”. Baza GUS obejmowała 37427 przypadków.

Możliwość korzystania z usług rekreacyjno-kulturalnych, dostęp do prasy, korzystanie z różnego typu szkoleń, kursów wpływają na pełniejszy rozwój jednostek, dają możliwość zaspokojenia potrzeb wyższego rzędu (Piekut 2014), dlatego też dokonano poniższego wyboru zmiennych do analizy. Podkategorie wydatków na dobra i usługi związane $\mathrm{z}$ rozwojem intelektualnym jednostek wykorzystane $\mathrm{w}$ badaniu to wydatki na: sprzęt audiowizualny, fotograficzny i informatyczny; usługi rekreacyjno-kulturalne; prasę, książki, artykuły piśmiene, kreślarskie i malarskie; turystykę zorganizowaną; szkolnictwo podstawowe i ponadpodstawowe (gimnazja, szkoły średnie i zawodowe); szkolnictwo policealne i wyższe; edukację niezdefiniowaną poziomem nauczania.

Do zbadania, zhierarchizowania czynników determinujących wydatki na rozwój intelektualny w wiejskich gospodarstwach domowych zastosowano analizę korelacji kanonicznej. Do przeprowadzenia badania wyselekcjonowano z bazy GUS gospodarstwa domowe zlokalizowane na wsi, które stanowiły 15742 przypadki. Przeprowadzenie analizy korelacji kanonicznej wymagało dokonania konwersji cech jakościowych na zmienne zero-jedynkowe (0-1). Zabieg ten wykonano $\mathrm{w}$ odniesieniu do zmiennych: typ biologiczny gospodarstwa domowego (np. gospodarstwa domowe: małżeństw z 1 dzieckiem na 
utrzymaniu; małżeństw z 2 dzieci na utrzymaniu; małżeństw z 3 dzieci na utrzymaniu; małżeństw z 4 i większą liczbą dzieci na utrzymaniu; matki lub ojca samotnie wychowujących dzieci na utrzymaniu; małżeństw $\mathrm{z}$ dziećmi na utrzymaniu i innymi osobami; bez dzieci na utrzymaniu itd.), faza cyklu rozwoju rodziny (osoby, małżeństwa młode, bez dzieci na utrzymaniu; rodziny z dziećmi $\mathrm{w}$ wieku przedszkolnym; rodziny $\mathrm{z}$ dziećmi w wieku szkolnym, rodziny z młodzieżą kształcącą się; osoby starsze, aktywne zawodowo bez dzieci na utrzymaniu; osoby starsze, nieaktywne zawodowo, bez dzieci na utrzymaniu), wykształcenie głowy gospodarstwa domowego, grupa społeczno-ekonomiczna. Założono, że zostaną omówione istotne $(\mathrm{p}<=0,05)$ pierwiastki kanoniczne (zespół zmiennych pierwotnych skorelowanych ze sobą i zhierarchizowanych według wkładów w nową zmienną). Do interpretacji pierwiastków kanonicznych zastosowano: wagi kanoniczne, które umożliwiają zrozumienie, jaki jest swoisty wkład każdej zmiennej w każdym zbiorze do danej sumy ważonej. Im jest większa ich wartość, tym jest większy ujemny lub dodatni wkład danej zmiennej do sumy (Stanisz 2002); oraz ładunki czynnikowe, czyli korelacje między zmiennymi kanonicznymi a zmiennymi w każdym zbiorze (Analiza ..., http).

W przeprowadzonym badaniu dokonano również porównania poziomu wydatków na dobra i usługi związane $\mathrm{z}$ rozwojem intelektualnym między wiejskimi i wielkomiejskimi gospodarstwami domowymi. Do analizy porównawczej wybrano wielkomiejskie gospodarstwa domowe, gdyż wydatki w tych gospodarstwach w największym stopniu różnią się od wydatków w wiejskich gospodarstwach domowych. Pomiędzy gospodarstwami domowymi zlokalizowanymi $\mathrm{w}$ miastach $\mathrm{z}$ różną liczbą mieszkańców istnieją istotne statystycznie różnice $\mathrm{w}$ poziomie wydatków na dobra i usługi związane $\mathrm{z}$ kształceniem. Im gospodarstwo domowe zlokalizowane jest $\mathrm{w}$ mieście $\mathrm{z}$ mniejszą liczbą mieszkańców, tym poziom wydatków na kształcenie jest bardziej zbliżony do gospodarstw zlokalizowanych na wsiach. Porównanie wiejskich gospodarstw domowych do jednej grupy gospodarstw domowych zlokalizowanych w określonej wielkości miastach staje się więc bardziej zasadne, niż do gospodarstw domowych zlokalizowanych w miastach w ogóle, bez względu na ich wielkość.

\section{Wydatki konsumpcyjne ${ }^{1}$ wolskich gospodarstwach domowych}

W wiejskich gospodarstwach domowych wydatki konsumpcyjne były mniejsze niż w gospodarstwach domowych ogółem. Wydatki w wiejskich gospodarstwach domowych wynosiły od 56\% wydatków na restauracje i hotele do blisko 94\% wydatków na żywność i napoje bezalkoholowe w porównaniu do wydatków w gospodarstwach domowych ogółem. Poziom wydatków na edukację

\footnotetext{
${ }^{1}$ Wydatki konsumpcyjne to wydatki w gospodarstwach domowych na dobra trwałego użytku (np. lodówka, pralka, meble) i nietrwałe (np. żywność, przybory szkolne, środki czystości) oraz usługi (np. edukacyjne, medyczne, kosmetyczne).
} 
w wiejskich gospodarstwach domowych wynosił 7 zł na osobę, podczas gdy w gospodarstwach domowych ogółem 12 zł na osobę, a w wielkomiejskich był największy - 29 zł na osobę. Wydatki na edukację w wiejskich gospodarstwach domowych stanowiły więc blisko $57 \%$ wydatków w gospodarstwach domowych ogółem i 24\% wydatków na edukację w wielkomiejskich gospodarstwach domowych. Podobnie, wydatki na usługi rekreacyjno-kulturalne były znacznie mniejsze na wsiach w porównaniu do ośrodków wielkomiejskich i gospodarstw domowych ogółem. Wydatki na usługi rekreacyjno-kulturalne wynosiły na osobę $56 \mathrm{zł} \mathrm{w}$ wiejskich gospodarstwach domowych, $170 \mathrm{zł} \mathrm{w}$ wielkomiejskich i 86 zł w gospodarstwach domowych ogółem.

W strukturze wydatków w wiejskich gospodarstwach domowych wydatki na edukację pochłaniały $0,9 \%$ budżetów domowych ogółem, w gospodarstwach domowych ogółem trochę więcej - 1,2\%, a w wielkomiejskich $-1,9 \%$. Wydatki na edukację stanowiły najmniejszy udział wśród wydatków konsumpcyjnych (rys. 1).

Usługi rekreacyjno-kulturalne $\mathrm{w}$ wiejskich gospodarstwach domowych pochłaniały $6,8 \%$ budżetów domowych ogółem, w wielkomiejskich $11,3 \%$, a w gospodarstwach domowych ogółem $-8,5 \%$.

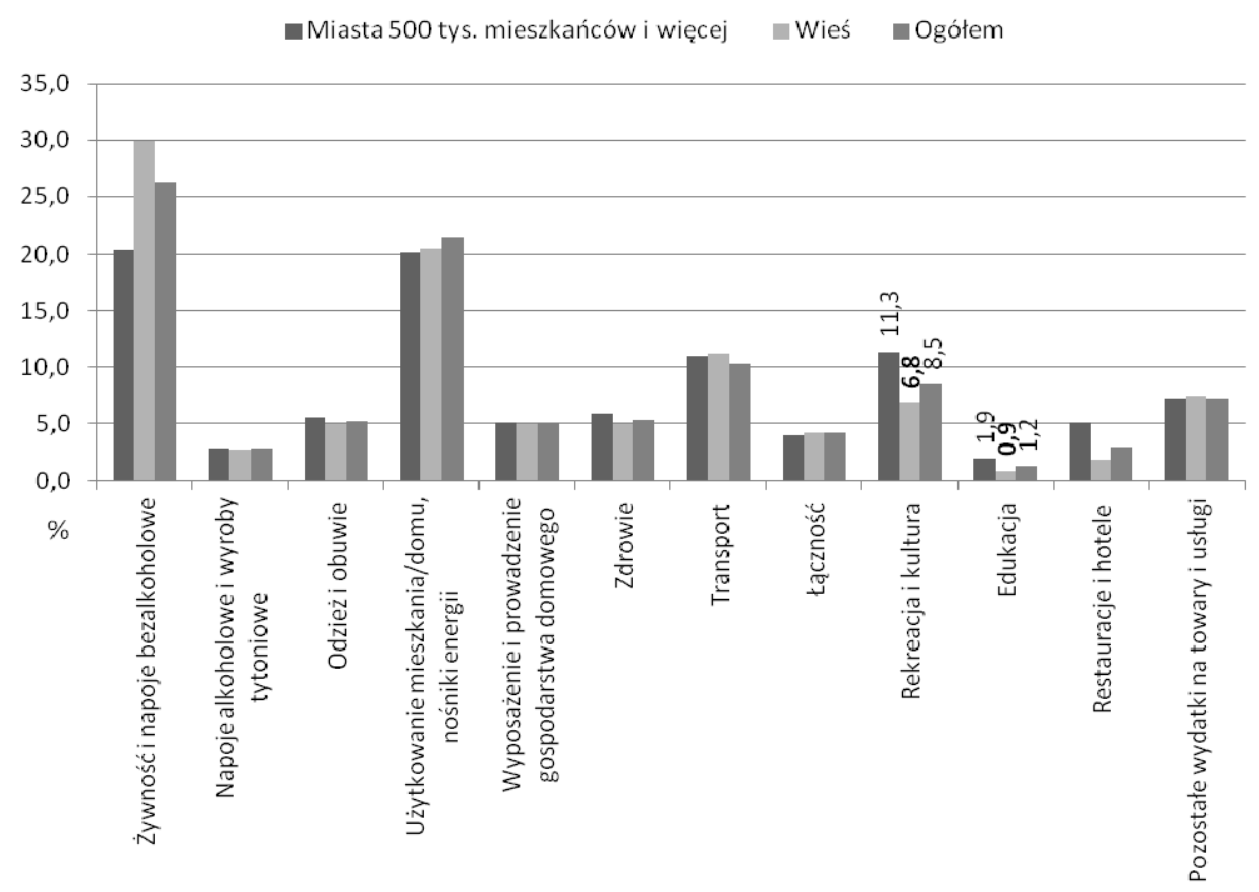

Rys. 1. Struktura wydatków konsumpcyjnych w gospodarstwach domowych w 2012 roku

Źródło: obliczenia własne na podstawie niepublikowanych danych GUS $\mathrm{z}$ badania budżetów gospodarstw domowych $\mathrm{w} 2012$ roku 


\section{Determinanty wydatków na rozwój intelektualny na wsiach}

W kolejnej części przeprowadzono analizę korelacji kanonicznej celem zhierarchizowania czynników determinujących wydatki na dobra i usługi związane $\mathrm{z}$ rozwojem intelektualnym członków gospodarstw domowych na wsiach. Omówiono pięć istotnych pierwiastków kanonicznych $(\mathrm{p}<0,05)$.

Na podstawie wartości wag kanonicznych oraz ładunków czynnikowych dla I najważniejszego pierwiastka kanonicznego (tab. 1) można stwierdzić, że głównymi determinantami wydatków na dobra i usługi związane z rozwojem intelektualnym mieszkańców wsi są dochody rozporządzalne na osobę oraz wykształcenie głowy gospodarstwa domowego. Im w gospodarstwie domowym były większe dochody rozporządzalne na jedną osobę i głowa rodziny posiadała wyższy poziom wykształcenia, tym można się było spodziewać większych wydatków na usługi w zakresie rekreacji i kultury, większych zakupów prasy, książek i artykułów piśmiennych oraz większych wydatków na turystykę zorganizowaną. Większe wydatki na wspomniane dobra i usługi związane z kształceniem wiązać było można też z takimi grupami społeczno-ekonomicznymi, jak: pracownicy na stanowiskach nierobotniczych oraz pracujący na własny rachunek.

Tabela 1

Wagi kanoniczne i ładunki czynnikowe dla I pierwiastka kanonicznego

\begin{tabular}{|l|c|c|l|c|c|}
\hline Zmienne niezależne & $\begin{array}{c}\text { Ladunki } \\
\text { czynni- } \\
\text { kowe }\end{array}$ & $\begin{array}{c}\text { Wagi } \\
\text { kanoniczne }\end{array}$ & $\begin{array}{c}\text { Zmienne zależne, } \\
\text { wydatki na: }\end{array}$ & $\begin{array}{c}\text { Ładunki } \\
\text { czynni- } \\
\text { kowe }\end{array}$ & $\begin{array}{c}\text { Wagi } \\
\text { kanoniczne }\end{array}$ \\
\hline $\begin{array}{l}\text { Dochód rozporzą- } \\
\text { dzalny gospodarstwa } \\
\text { na 1osobę }\end{array}$ & 0,637 & 0,533 & $\begin{array}{l}\text { Usługi w zakresie } \\
\text { rekreacji i kultury }\end{array}$ & 0,640 & 0,524 \\
\hline $\begin{array}{l}\text { Wyższe wykształce- } \\
\text { nie głowy rodziny }\end{array}$ & 0,636 & 0,348 & $\begin{array}{l}\text { Gazety, czasopi- } \\
\text { sma, książki, inne } \\
\text { artykuły piśmienne }\end{array}$ & 0,542 & 0,439 \\
\hline $\begin{array}{l}\text { Małżeństwa z dzieć- } \\
\text { mi w wieku szkol- } \\
\text { nym }\end{array}$ & 0,251 & 0,405 & $\begin{array}{l}\text { Szkolnictwo pod- } \\
\text { stawowe, w tym } \\
\text { przedszkolne }\end{array}$ & 0,415 & 0,360 \\
\hline $\begin{array}{l}\text { Gospodarstwa domo- } \\
\text { we utrzymujące się } \\
\text { z pracy na własny } \\
\text { rachunek }\end{array}$ & 0,277 & 0,249 & $\begin{array}{l}\text { Turystyka } \\
\text { zorganizowana }\end{array}$ & 0,457 & 0,348 \\
\hline $\begin{array}{l}\text { Gospodarstwa domo- } \\
\text { we pracowników na } \\
\text { stanowiskach niero- } \\
\text { botniczych }\end{array}$ & 0,453 & 0,241 & & & \\
\hline
\end{tabular}

Źródło: obliczenia własne na podstawie niepublikowanych danych GUS z badania budżetów gospodarstw domowych w 2012 roku. 
Wagi kanoniczne i ładunki czynnikowe dla II pierwiastka (tab. 2) wskazały, że w gospodarstwach domowych z młodzieżą kształcąca się, w gospodarstwach osób młodych, bez dzieci na utrzymaniu i w gospodarstwach domowych o korzystniejszej sytuacji materialnej można było się spodziewać większych wydatków na usługi rekreacyjno-kulturalne. Mniejszych wydatków na rzeczone usługi można było oczekiwać $\mathrm{w}$ gospodarstwach domowych $\mathrm{z}$ większą liczbą dzieci na utrzymaniu.

Tabela 2

Wagi kanoniczne i ładunki czynnikowe dla II pierwiastka kanonicznego

\begin{tabular}{|l|c|c|c|c|c|}
\hline Zmienne niezależne & $\begin{array}{c}\text { Ładunki } \\
\text { czynni- } \\
\text { kowe }\end{array}$ & $\begin{array}{c}\text { Wagi } \\
\text { kanoniczne }\end{array}$ & $\begin{array}{c}\text { Zmienne zależne, } \\
\text { wydatki na: }\end{array}$ & $\begin{array}{c}\text { Ładunki } \\
\text { czynni- } \\
\text { kowe }\end{array}$ & $\begin{array}{c}\text { Wagi } \\
\text { kanoniczne }\end{array}$ \\
\hline $\begin{array}{l}\text { Małżeństwa z mło- } \\
\text { dzieżą kształcącą się }\end{array}$ & 0,108 & 0,362 & $\begin{array}{l}\text { Szkolnictwo pod- } \\
\text { stawowe, w tym } \\
\text { edukacja przed- } \\
\text { szkolna }\end{array}$ & $-0,733$ & $-0,750$ \\
\hline $\begin{array}{l}\text { Dochód rozporzą- } \\
\text { dzalny }\end{array}$ & 0,424 & 0,287 & $\begin{array}{l}\text { Usługi w zakresie } \\
\text { rekreacji i kultury }\end{array}$ & 0,537 & 0,565 \\
\hline $\begin{array}{l}\text { Małżeństwa osób } \\
\text { młodych }\end{array}$ & 0,375 & 0,204 & & & \\
\hline $\begin{array}{l}\text { Małżeństwa z dzieć- } \\
\text { mi w wieku przed- } \\
\text { szkolnym }\end{array}$ & $-0,672$ & $-0,437$ & & & \\
\hline Liczba dzieci & $-0,561$ & $-0,342$ & & & \\
\hline
\end{tabular}

Źródło: obliczenia własne na podstawie niepublikowanych danych GUS z badania budżetów gospodarstw domowych w 2012 roku.

Na podstawie wartości wag kanonicznych i ładunków czynnikowych dla III pierwiastka kanonicznego (tab. 3) można stwierdzić, że w gospodarstwach domowych z większą liczbą dzieci na utrzymaniu można było się spodziewać większych wydatków na książki, artykuły piśmienne oraz na edukację w gimnazjach, szkołach zasadniczych zawodowych i średnich.

$\mathrm{Na}$ podstawie wag kanonicznych i ładunków czynnikowych dla IV pierwiastka kanonicznego (tab. 4) stwierdzono, że w gospodarstwach domowych $\mathrm{z}$ większą liczbą dzieci na utrzymaniu oraz w gospodarstwach domowych małżeństw z młodzieżą kształcącą się można było spodziewać się większych wydatków na szkolnictwo wyższe. 
Tabela 3

Wagi kanoniczne i ładunki czynnikowe dla III pierwiastka kanonicznego

\begin{tabular}{|l|c|c|l|c|c|}
\hline Zmienne niezależne & $\begin{array}{l}\text { Ladunki } \\
\text { czynni- } \\
\text { kowe }\end{array}$ & $\begin{array}{c}\text { Wagi } \\
\text { kanoniczne }\end{array}$ & $\begin{array}{l}\text { Zmienne zależne, } \\
\text { wydatki na: }\end{array}$ & $\begin{array}{c}\text { Ładunki } \\
\text { czynni- } \\
\text { kowe }\end{array}$ & $\begin{array}{c}\text { Wagi } \\
\text { kanoniczne }\end{array}$ \\
\hline $\begin{array}{l}\text { Małżeństwa z dzieć- } \\
\text { mi w wieku przed- } \\
\text { szkolnym }\end{array}$ & $-0,571$ & $-0,556$ & $\begin{array}{l}\text { Gazety, czaso- } \\
\text { pisma, książki } \\
\text { i artykuły piśmie- } \\
\text { ne }\end{array}$ & 0,607 & 0,611 \\
\hline $\begin{array}{l}\text { Małżeństwa z dzieć- } \\
\text { mi w wieku szkol- } \\
\text { nym }\end{array}$ & 0,712 & 0,476 & $\begin{array}{l}\text { Gimnazja, szkoły } \\
\text { zasadnicze zawo- } \\
\text { dowe, średnie } \\
\text { techniczne } \\
\text { i zawodowe }\end{array}$ & 0,528 & 0,505 \\
\hline $\begin{array}{l}\text { Liczba dzieci na } \\
\text { utrzymaniu }\end{array}$ & 0,496 & 0,283 & $\begin{array}{l}\text { Szkolnictwo pod- } \\
\text { stawowe, w tym } \\
\text { przedszkolne }\end{array}$ & $-0,493$ & $-0,503$ \\
\hline
\end{tabular}

Źródło: obliczenia własne na podstawie niepublikowanych danych GUS z badania budżetów gospodarstw domowych w 2012 roku.

Tabela 4

Wagi kanoniczne i ładunki czynnikowe dla IV pierwiastka kanonicznego

\begin{tabular}{|l|c|c|c|c|c|}
\hline Zmienne niezależne & $\begin{array}{c}\text { Ładunki } \\
\text { czynni- } \\
\text { kowe }\end{array}$ & $\begin{array}{c}\text { Wagi } \\
\text { kanoniczne }\end{array}$ & $\begin{array}{c}\text { Zmienne zależne, } \\
\text { wydatki na: }\end{array}$ & $\begin{array}{c}\text { Ładunki } \\
\text { czynni- } \\
\text { kowe }\end{array}$ & $\begin{array}{c}\text { Wagi } \\
\text { kanoniczne }\end{array}$ \\
\hline Liczba dzieci & 0,262 & 0,593 & $\begin{array}{c}\text { Szkolnictwo } \\
\text { wyższe }\end{array}$ & 0,860 & 0,862 \\
\hline $\begin{array}{l}\text { Małżeństwa z mło- } \\
\text { dzieżą kształcącą się }\end{array}$ & 0,767 & 0,828 & & & \\
\hline
\end{tabular}

Źródło: obliczenia własne na podstawie niepublikowanych danych GUS z badania budżetów gospodarstw domowych w 2012 roku.

$\mathrm{Na}$ podstawie wag kanonicznych i ładunków czynnikowych dla $\mathrm{V}$ pierwiastka kanonicznego (tab. 5) można stwierdzić, że w gospodarstwach domowych małżeństw z jednym dzieckiem na utrzymaniu, z większą liczbą osób można było się spodziewać większych wydatków na sprzęt audiowizualny, fotograficzny i informatyczny, a mniejszych na prasę, książki i artykuły piśmienne. Podobnych zależności można było oczekiwać w gospodarstwach domowych, w których głowa rodziny legitymowała się gimnazjalnym poziomem wykształcenia. 
Tabela 5

Wagi kanoniczne i ładunki czynnikowe dla V pierwiastka kanonicznego

\begin{tabular}{|l|c|c|l|r|r|}
\hline \multicolumn{1}{|c|}{$\begin{array}{c}\text { Zmienne } \\
\text { niezależne }\end{array}$} & $\begin{array}{c}\text { Ładunki } \\
\text { czynni- } \\
\text { kowe }\end{array}$ & $\begin{array}{c}\text { Wagi } \\
\text { kanoniczne }\end{array}$ & $\begin{array}{l}\text { Zmienne zależne, } \\
\text { wydatki na: }\end{array}$ & $\begin{array}{c}\text { Ładunki } \\
\text { czynni- } \\
\text { kowe }\end{array}$ & $\begin{array}{c}\text { Wagi } \\
\text { kanoniczne }\end{array}$ \\
\hline Liczba osób & 0,055 & 0,744 & $\begin{array}{l}\text { Sprzęt audiowi- } \\
\text { zualny, fotogra- } \\
\text { ficzny i informa- } \\
\text { tyczny }\end{array}$ & 0,632 & 0,656 \\
\hline $\begin{array}{l}\text { Gimnazjalne } \\
\text { wykształcenie } \\
\text { głowy rodziny }\end{array}$ & 0,315 & 0,739 & $\begin{array}{l}\text { Gimnazja, szkoły } \\
\text { zasadnicze, śred- } \\
\text { nie techniczne } \\
\text { i zawodowe, licea }\end{array}$ & 0,415 & 0,475 \\
\hline $\begin{array}{l}\text { Małżeństwa } \\
\text { z 1 dzieckiem na } \\
\text { utrzymaniu }\end{array}$ & 0,516 & 0,718 & $\begin{array}{l}\text { Gazety, czasopi- } \\
\text { sma, książki, arty- } \\
\text { kuły piśmienne }\end{array}$ & $-0,359$ & $-0,417$ \\
\hline
\end{tabular}

Źródło: obliczenia własne na podstawie niepublikowanych danych GUS z badania budżetów gospodarstw domowych w 2012 roku.

\section{Wydatki na kształcenie w zależności o typów gospodarstw domowych}

Kolejna część analizy dotyczy porównania miesięcznych wydatków na osobę na dobra i usługi związane $\mathrm{z}$ rozwojem intelektualnym członków gospodarstw w podziale na wielkomiejskie i wiejskie gospodarstwa domowe w zależności od różnych typów tych gospodarstw. Generalnie w gospodarstwach domowych zlokalizowanych w miastach z 500000 i więcej mieszkańców wydatki na dobra i usługi związane $\mathrm{z}$ rozwojem intelektualnym jednostek są większe niż $\mathrm{w}$ wiejskich gospodarstwach domowych.

Analiza wydatków na dobra i usługi związane z kształceniem w zależności od lokalizacji gospodarstwa domowego i grupy dochodowej dowiodła, że wraz ze wzrostem poziomu zamożności $w$ gospodarstwach domowych wzrastały wydatki na wszystkie kategorie dóbr i usług (rys. 2). Największe wydatki ponoszono na usługi w zakresie rekreacji i kultury, z tym że w wiejskich gospodarstwach domowych poziom tych wydatków był znacznie mniejszy, i tak na przykład w I grupie dochodowej rzeczone wydatki pochłaniały na osobę blisko $25 \mathrm{zł} \mathrm{w}$ wielkomiejskich gospodarstwach domowych i ponad $15 \mathrm{zł} \mathrm{w}$ wiejskich gospodarstwach, w II grupie dochodowej odpowiednio 37 zł i 24 zł, a w III grupie ponad $73 \mathrm{zł}$ i blisko $41 \mathrm{zł}$.

Wydatki na sprzęt audiowizualny, fotograficzny i informatyczny w wiejskich gospodarstwach domowych z I i II grupy nie przekroczyły 5,5 zł, podczas gdy $\mathrm{w}$ wielkomiejskich gospodarstwach domowych z I grupy dochodowej wynosiły ponad 6,6 zł na osobę. W III grupie dochodowej wydatki na sprzęt 
audiowizualny, fotograficzny i informatyczny w wiejskich gospodarstwach domowych były ponad dwukrotnie mniejsze niż w wielkomiejskich gospodarstwach domowych.

Wydatki ponoszone na prasę, książki i artykuły piśmienne w wiejskich gospodarstwach domowych kształtowały się, w zależności od grupy dochodowej, od 8 zł do blisko 12 zl, podczas gdy w wielkomiejskich wynosiły od ponad $11 \mathrm{zł}$ do $25 \mathrm{zł}$.

Wydatki na turystykę zorganizowaną wynosiły w wiejskich gospodarstwach domowych od niepelnych $3 \mathrm{zl}$ na osobę w I grupie dochodowej do blisko $23 \mathrm{zł}$ na osobę w III grupie dochodowej. W wielkomiejskich gospodarstwach domowych wydatki na turystykę zorganizowaną stanowiły relatywnie więcej, tj. od ponad $10 \mathrm{zł}$ na osobę w I grupie dochodowej do blisko $63 \mathrm{zł}$ na osobę w III grupie dochodowej.

W wielkomiejskich gospodarstwach domowych ponoszono też znacznie większe wydatki na edukację podstawową i gimnazjalną $\mathrm{w}$ porównaniu do gospodarstw zlokalizowanych na wsi.

Wyróżniający się poziom wydatków na edukację niezdefiniowaną poziomem nauczania (kursy, szkolenia) zauważono $\mathrm{w}$ wielkomiejskich gospodarstwach domowych z III grupy dochodowej, ponad 13 zł na osobę. W pozostałych grupach gospodarstw domowych wydatki na omawianą potrzebę nie przekroczyły 3 zł na osobę.

Analiza poziomu wydatków na dobra i usługi związane z rozwojem intelektualnym w zależności od lokalizacji gospodarstw domowego i poziomu wykształcenia głowy rodziny dowiodła, że w miarę wzrostu poziomu wykształcenia głowy rodziny wzrastały wydatki na omawiane dobra i usługi (rys. 3). Analiza ta potwierdza wcześniejsze wyniki badań (Block i in. 2013), że w miarę wzrostu wykształcenia rodziców wzrastają wydatki na kształcenie. M. Rokicka i U. Sztanderska (2013) wskazały, że to przede wszystkim wykształcenie matki ma wpływ na ponoszenie wydatków edukacyjnych i ich wysokość.

$\mathrm{W}$ gospodarstwach domowych, w których głowa rodziny legitymowała się podstawowym poziomem wykształcenia wydatki na usługi rekreacyjno-kulturalne były o prawie połowę mniejsze w wiejskich gospodarstwach domowych w porównaniu do wielkomiejskich gospodarstw, podobnie sytuacja wyglądała w pozostałych typach gospodarstw domowych wyróżnionych ze względu na wykształcenie głowy rodziny.

Wydatki na sprzęt audiowizualny, fotograficzny i informatyczny kształtowały się w wielkomiejskich gospodarstwach domowych od około $8 \mathrm{zl}$ na osobę do ponad 29 zł na osobę, a wiejskich od 3 zł do ponad $10 \mathrm{zł.}$

Prasa, książki i artykuły piśmienne w zależności od wykształcenia głowy rodziny pochłaniały na osobę od $8 \mathrm{zł}$ do $28 \mathrm{zł} \mathrm{w}$ wielkomiejskich gospodarstwach domowych oraz od ponad $5 \mathrm{zł}$ do ponad $15 \mathrm{zł} \mathrm{w}$ wiejskich gospodarstwach domowych. 


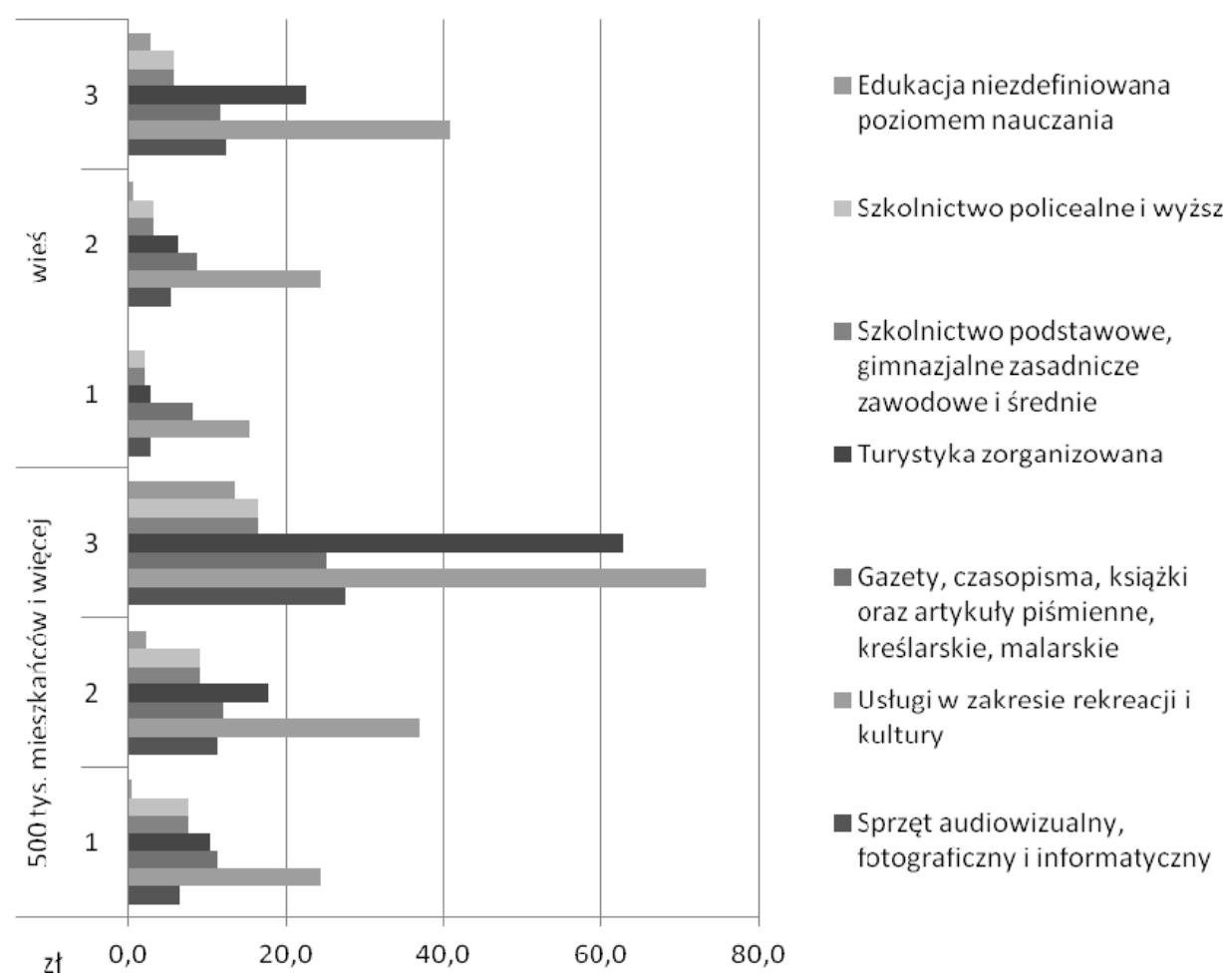

Rys. 2. Miesięczne wydatki na dobra i usługi związane z edukacją w zależności od grupy dochodowej* w polskich gospodarstwach domowych w 2012 roku (w zł na osobę)

* gospodarstwa domowe podzielono na trzy równoliczne grupy, wartości graniczne, które wyznaczały linie podziałów, to 959 zł na osobę oraz 1515 zł na osobę

Źródło: obliczenia własne na podstawie niepublikowanych danych GUS $\mathrm{z}$ badania budżetów gospodarstw domowych w 2012 roku

Wydatki na turystykę zorganizowaną kształtowały się w największych miastach od blisko 5 zł na osobę w gospodarstwach z głową rodziny z najniższym poziomem wykształcenia do blisko $74 \mathrm{zł} \mathrm{w}$ gospodarstwach z głową rodziny z wyższym poziomem wykształcenia. W wiejskich gospodarstwach domowych wydatki te były mniejsze i wynosiły od około 2 zł na osobę w gospodarstwach domowych prowadzonych przez osoby najmniej wykształcone do 24 zł na osobę w gospodarstwach domowych, w których głowa rodziny legitymowała się wyższym poziomem wykształcenia.

Poziom wydatków na edukację niezdefiniowaną poziomem nauczania w zależności od wykształcenia głowy rodziny kształtował się od około 3 zł do blisko $16 \mathrm{zł} \mathrm{w}$ wielkomiejskich gospodarstwach domowych oraz od 0,2 zł do około 4 zł w wiejskich gospodarstwach domowych. Większe wydatki na edukację niezdefiniowaną poziomem nauczania $\mathrm{w}$ gospodarstwach domowych z głowami rodziny legitymującymi się wyższym wykształceniem zapewne 
można wiązać $\mathrm{z}$ większymi dochodami $\mathrm{w}$ tych gospodarstwach domowych, a być może także $\mathrm{z}$ większą świadomością członków gospodarstw domowych $\mathrm{w}$ zakresie roli wykształcenia $\mathrm{w}$ życiu, nie tylko pozyskanego $\mathrm{w}$ trakcie obowiązku szkolnego. Inne badania potwierdzają (Badora 2013) zależność, że na pozalekcyjne płatne zajęcia edukacyjne i ogólnorozwojowe wpływa głównie poziom wykształcenia rodziców.

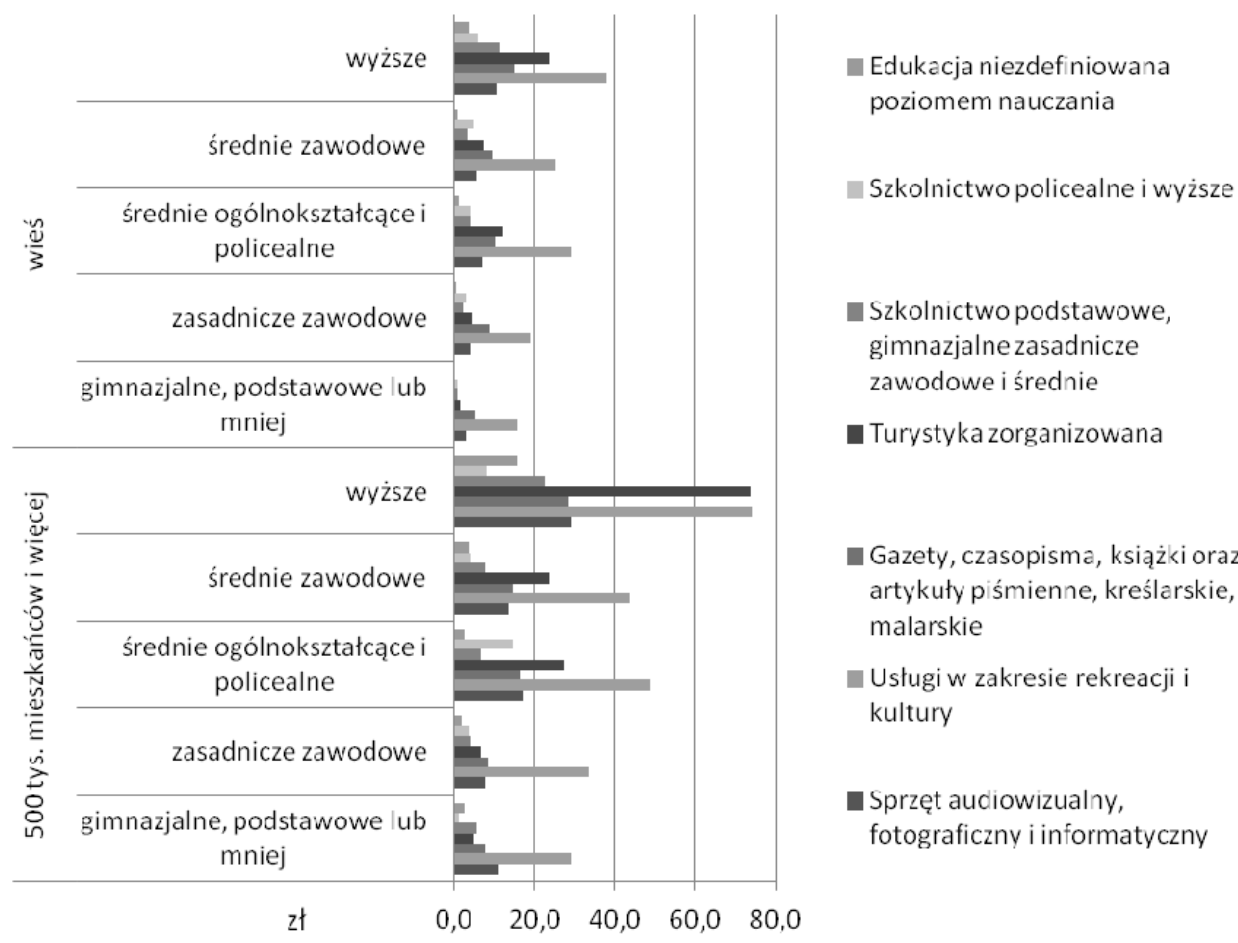

Rys. 3. Miesięczne wydatki na dobra i usługi związane z edukacją w zależności od wykształcenia głowy gospodarstwa domowego w Polsce w 2012 roku (w zł na osobę)

Źródło: obliczenia własne na podstawie niepublikowanych danych GUS $\mathrm{z}$ badania budżetów gospodarstw domowych w 2012 roku

Analiza wydatków na dobra i usługi związane z rozwojem intelektualnym członków gospodarstw domowych w zależności od fazy cyklu rozwoju rodziny i lokalizacji gospodarstwa domowego dowiodła, że w gospodarstwach osób młodych, bez dzieci na utrzymaniu, zarówno zlokalizowanych na wsiach, jak $\mathrm{i}$ w miastach, najwięcej przeznaczano na rzeczone dobra i usługi (rys. 4). W pozostałych typach gospodarstw domowych ze względu na fazę cyklu rozwoju rodziny największe wydatki na rzeczone dobra i usługi zaobserwowano w gospodarstwach domowych małżeństw z dziećmi w wieku szkolnym. 


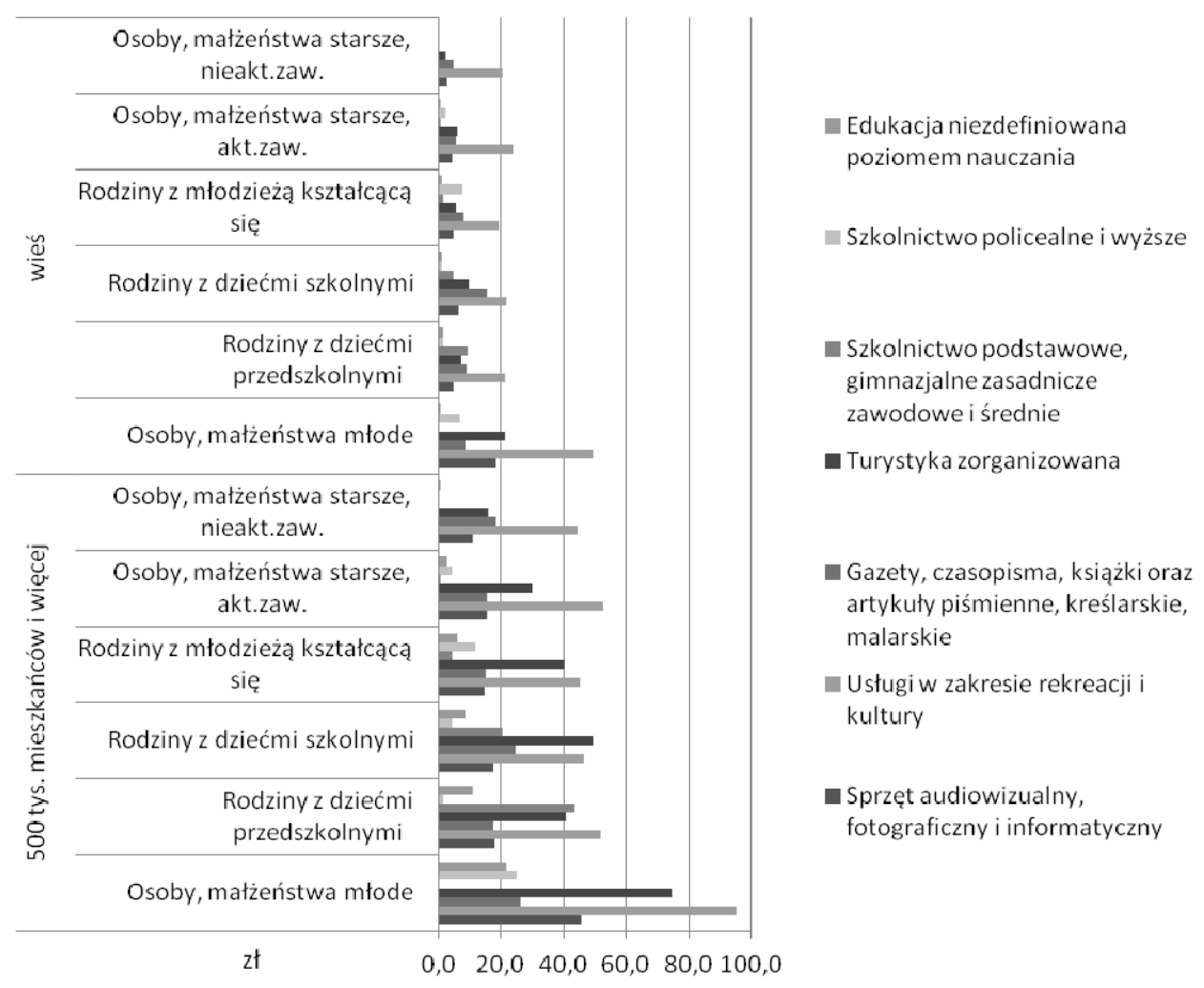

Rys. 4. Miesięczne wydatki na dobra i usługi związane $\mathrm{z}$ edukacją $\mathrm{w}$ zależności od fazy cyklu rozwoju rodziny* w Polsce w 2012 roku (w zł na osobę) *pojęcie cyklu rozwoju rodziny zostało zaproponowane przez Duvall`a. W niniejszym podziale wyróżniono siedem faz, które przechodzi rodzina w zależności od etapu życia i zadań jakie pełni

Źródło: obliczenia własne na podstawie niepublikowanych danych GUS $\mathrm{z}$ badania budżetów gospodarstw domowych w 2012 roku

Analiza poziomu wydatków na dobra i usługi związane z rozwojem intelektualnym członków gospodarstw domowych w zależności od wielkości gospodarstwa domowego i lokalizacji gospodarstwa domowego pokazała, że wraz ze wzrostem liczby osób w rodzinie zmniejszał się poziom wydatków na jedną osobę na usługi rekreacyjno-kulturalne (rys. 5). Zaobserwowano także, że poziom wydatków na osobę na turystykę zorganizowaną i edukację niezdefiniowaną poziomem nauczania w gospodarstwach domowych 4-osobych był większy niż w mniej osobowych. 


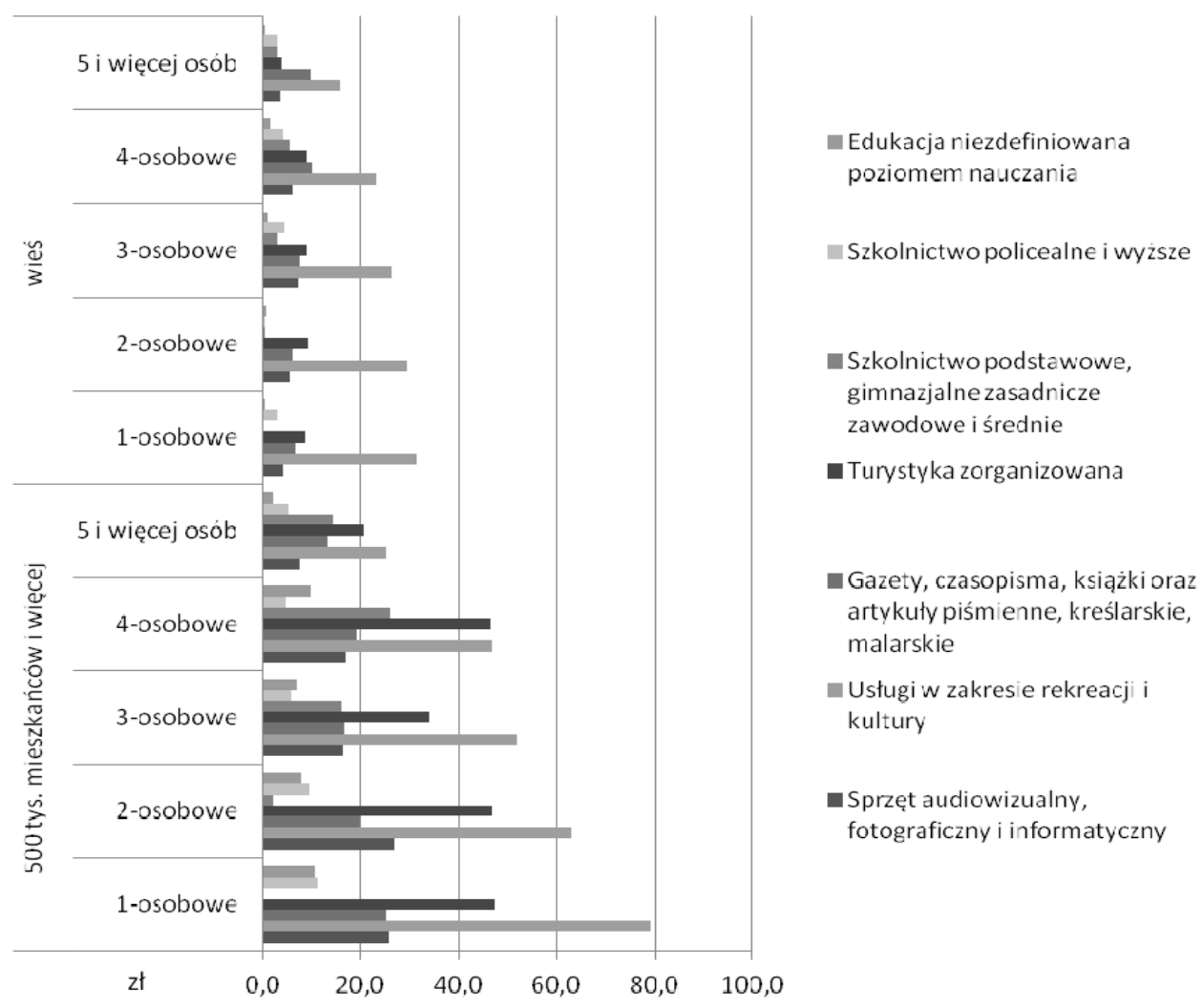

Rys. 5. Miesięczne wydatki na dobra i usługi związane $\mathrm{z}$ edukacją w zależności od wielkości gospodarstwa domowego w Polsce w 2012 roku (w zł na osobę)

Źródło: obliczenia własne na podstawie niepublikowanych danych GUS $\mathrm{z}$ badania budżetów gospodarstw domowych w 2012 roku

\section{Podsumowanie}

Na podstawie przeprowadzonych analiz można stwierdzić, że cel badania został osiągnięty. Zhierarchizowano cechy determinujące wydatki na rozwój intelektualny członków gospodarstw domowych na wsiach oraz dokonano porównania tych wydatków między różnymi typami gospodarstw domowych zlokalizowanych na wsiach i w największych miastach.

Wśród dwunastu grup towarów i usług konsumpcyjnych wydatki na edukację są najmniejsze. Na wsi poziom i udział wydatków jest zdecydowanie mniejszy niż w wielkomiejskich gospodarstwach domowych. Najważniejsze determinanty wydatków na rozwój intelektualny członków gospodarstwa domowego to dochód rozporządzalny na osobę i poziom wykształcenia głowy rodziny. Większy dochód na osobę, wyższy poziom wykształcenia głowy rodziny, utrzymywanie 
się z pracy na własny rachunek lub z pracy na stanowiskach nierobotniczych można łączyć z większymi wydatkami na usługi rekreacji i kultury, na turystykę zorganizowaną, na prasę i artykuły piśmienne. Istotność dochodów rozporządzalnych oraz poziomu wykształcenia głowy rodziny w badaniu wydatków na edukację podkreślał też A. Matuszczak (2014).

W wiejskich gospodarstwach domowych odnotowano mniejsze wydatki na wszystkie dobra związane z kształceniem w konfrontacji do porównywalnych gospodarstw domowych zlokalizowanych w największych miastach. Różnice między miejskimi i wiejskimi gospodarstwami domowymi są wynikiem oddziaływania kompleksu czynników o różnorakim charakterze. Należy pamiętać też o czynnikach egzogennych, np. sytuacji na rynku pracy, dostępności jednostek rekreacyjno-kulturalnych na tych obszarach, które nie były uwzględnione w poniższej analizie, a zapewne mają niebywały wpływ na omawiany problem. Istotną grupą czynników różnicujących konsumpcję w wielkomiejskich i wiejskich gospodarstw domowych są czynniki infrastrukturalne, gdyż dostępność instytucji służących zaspokojeniu potrzeb ludności może stymulować, hamować bądź nawet uniemożliwiać realizację pożądanych wzorców konsumpcji. Dostępność instytucji, przede wszystkim kulturalnych, od lat plasuje ludność wiejską w relatywnie gorszym położeniu aniżeli ludność zamieszkującą miasta (Gutkowska, Piekut 2014), choć w ostatnich latach obserwuje się pewną poprawę w tym zakresie.

\section{LITERATURA}

Analiza skupień, Electronic Statistics Textbook, StatSoft., http://www.statsoft.pl/textbook/stathome_stat.html?http\%3A\%2F\%2Fwww.statsoft.pl\%2Ftextbook\%2Fstcluan .html (dostęp: 23.07.2014).

Badora B., 2013, Wydatki rodziców na edukację dzieci w roku szkolnym 2013/2014. Komunikat z badań, CBOS, Warszawa.

Block A. i in., 2013, Koszty edukacji ponadgimnazjalnej i policealnej. Raport, Instytut Badań Edukacyjnych, Warszawa.

Budzety gospodarstw domowych w 2012 roku, GUS, Warszawa (niepublikowane dane).

Czapiewska G., 2014, Kapitat społeczno-kulturowy na obszarach wiejskich województwa pomorskiego - geneza i współczesne trendy zmian, [w:] Regionalny wymiar przemian polskiej wsi - aspekty społeczne i środowiskowe, ,Studia Obszarów Wiejskich", 35, s. 122-136.

Dresler E., 2003, Spoteczeństwo obywatelskie - nowa idea obecna w strategii rozwoju lokalnego obszarów wiejskich, [w:] Strategia rozwoju lokalnego. Aspekty instytucjonalne, 1, SGGW, Warszawa, s. 179-189.

Gutkowska K., Piekut M., 2014, Konsumpcja w wiejskich gospodarstwach domowych, „Wieś i Rolnictwo”, 4(165).

Kołaczek B., 2011, Edukacja i inwestycje rodziny w ksztatcenie młodego pokolenia a rynek pracy, „Polityka Społeczna”, 38/10(451), s. 1-8. 
Matuszczak A., 2014, Edukacja przedszkolna na polskiej wsi w okresie transformacji gospodarczej, „Progress in Economic Sciences”, 1, s. 165-177.

Piekut M., 2014, Nierówności w wydatkach na edukację w europejskich gospodarstwach domowych, [w:] „Nierówności społeczne a wzrost gospodarczy. W kierunku zintegrowanego rozwoju", 39, Uniwersytet Rzeszowski, s. 250-261.

Rokicka M., Sztanderska U., 2013, Cechy społeczno-ekonomiczne rodziny a ponoszenie wydatków na prywatne dobra i usługi edukacyjne, „Edukacja” 121(1).

Stanisz A., 2002, Korelacja kanoniczna, „Medycyna Praktyczna”, 6.

Wójcik M., 2008, Przemiany społeczno-gospodarcze wsi aglomeracji łódzkiej w okresie transformacji ustrojowej, Wydawnictwo Uniwersytetu Łódzkiego, Łódź.

\title{
EXPENDITURE ON GOODS AND SERVICES RELATED TO INTELLECTUAL DEVELOPMENT HOUSEHOLD MEMBERS FROM THE PERSPECTIVE OF RURAL HOUSEHOLD BUDGETS
}

\begin{abstract}
The article focuses on the analysis of the characteristics that determine spending on education in rural households, and compared the level of expenditure on education depending on where location. Includes households located in the largest cities and villages. Despite the many transformations of the Polish countryside there are still significant differences in spending on education between households of the cities and the countryside.
\end{abstract}

Key words: consumption, household, intellectual development, household budgets, rural areas.

Dr inż. Marlena Piekut Kolegium Nauk Ekonomicznych i Społecznych Politechnika Warszawska, Filia w Płocku 